\section{AN ADDRESS}

\section{THE STUDY OF PATHOLOGY.}

Delivered at the University of Aberdeen, Session 1882.

By D. J. HAMILTON, M.B., F.R.C.S.E., etc., Professor of Pathological Anatomy (the Sir Erasmus Wilson Chair), in the University of Aberdeen.

IT is usual, when delivering an inaugural address in connection with a professorial appointment, to commence by relating the past history of the Chair, and by sketching the lives of those who have been the present occupant's predecessors. On this occasion, however, these timehonoured customs are uncalled for, seeing that predecessors I have none, and as yet historical traditions have not had time to accumulate.

As regards the history of the foundation of the Chair, however, it will be incumbent upon me to say a few words, seeing that this is a subject upon which we all, as connecte-' with this university, ought to be familiar. For many years past, the want of a Chair of Pathology has been much felt among those who had the interests of the university at heart. Hitherto, pathology has been taught, and has been well taught, so far as the circumstances would admit, not as a special subject, but simply as a part of the courses of physic, surgery, the institutes of medicine, obstetrics, and medical jurisprudence. It has not formed a separate branch in the medical curriculum. Of late, however, the subject has grown so rapidly, and has now assumed such colossal dimensions, that the necessity of teaching it separately, and in a systematic manner, has become more and more called for. The chief obstacle in the way of accomplishing this has been the procuring of an endowment; but, after several schemes had been proposed, the diffculty, as you all know, was solved by the munificent gift of $£$ ro,000 to this end by Sir Erasmus Wilson.

Sir Erasmus Wilson was the son of Dr. Wilson, a native of the parish of Gartly, about a mile from Huntly. His father was in the King's navy, and was educated in this university. At some perior after this, however, he removed to London in order to be nearer his ship, and Sir Erasmus Wilson owes his medical education to the southern metropolis. It may be conjectured, however, that, like all true Scotchmen, Sir Erasmus Wilson had 2 warm side $f_{i} \mathrm{r}$ his birthplace and scene of his early youth. Amidst the distractions of a large practice, and after the greater part of a life spent in London, he has not forgotten Aberdeenshire; and, in a princely manner, has done honour to the memory of his father by establishing the present Chair in the university where the latter received his education. There are few in the medical profession at the present day, whose pursuits present such a varied aspect, and whose career has been marked with such signal success. Commencing life as an anatomist, Sir Erasmus Wilson made this subject a specialty; and did much, by writing and otherwise, to advance its claims, and to make its teaching easy. You all know, I dare say, the Vade Mecum, Dissector's Manual, and Anatomical Plates, which bear his name; and I doubt not many of you have profited by their use. In the cousse of time, the founder of our Pathological Chair, however, renounced his anatomical teachizg to engage in the specialty - that of the diseases of the skin-with which his name medically is chiefly associated, and in which his world-wide reputation has been gained. The number of works which he has published on this subject is too great to be erumerated on the present occasion; but well worthy to be classical models to you in your study of this most important set of diseases. In the year 1869, he founded the Chair and established the Museum of Dermatology in the London College of Surgeons, and was appointed its first professor. The College of Surgeons has of late done him the further honour of electing him its president. One of the subjects on which Sir Erasmus Wilson is best popularly known is that of Egyptian archæology. I need hardly remind you of the works he has published in this domain, and of the national benefit he has conferred ' $y$ the transference of one of the Alexandrian obelisks to the banks of the Thames; and, lastly, although not least of his charitable gifts, is that of the new wing to the Margate Royal Sea-Bathing Infirmary, built at a cost of over $£ 30,000$. It is something for a man to leave money in bequests for educational and charitable purposes; but, when it is handed over as a gift during the life of the donor, it means a very great deal more; and, as such, the act demands correspondingly greater admiration. There is, however, always this to be remembered, that gifts made during a lifetime for educa'ional or charitable purposes, such as the present, reflect their reward in the pleasure afforded by watching the progress of the object which they are intended to foster. I trust that the founder of the Pathological Chair in this university may be able tu visit Aberdeen before long, and that a band of ardent young pathologists will be ready to welcome him to the precincts of Marischal College.

The example set by Sir Erasmus Wilson might well be imitated by many outside the profession. Medical education in this country is sadly in want of support such as that afforded on the present occasion, for, while our Government will vote enormous sums to fit out expeditions to seek for the North Pole, and other such schemes, the subject of equipping medical men so as to render them competent for the responsible duties before them, seems to be a matter of second or thirdrate importance. Seeing that it is the community at larse who really gain by the higher education of their medical men, or rather, knowing as we all do that it is they who suffer by their blunders, one would think that, under the circumstances, it should be their direct interest to encourage a higher standard of proficiency by affording teaching bodies the means of rendering their instruction as comprehensive as possible.

There is another, however, who, in connection with the foundation of this Chair, must also be mentioned. I refer to Emeritus. Professor Pirrie. It would ill become me to sjeak of the deserts of one whom you have had opportunities of knowing so much better than I; but, when I remind you that it is to the lifelong friendship which has existed between Professor Pirrie and Sir Erasmus Wilson that we possess the present Chair of Pathology, you will understand that the whole of us owe him a debt of gratitude. Natives of the same village, and stead. fast friends when grown into manhood, they have borse into old age the freshness of a schoolboy friendship -a friendship which to us has been of the most material benefit. Retiring from office with the consciousness of a life well spent, of duties thoroughly performed, and with the feeling of having aided in doing a good act as a climax to an illustrious university career, it will be an aciditional comfort to Professor Pirrie to think that his name will be handed down to posterity as one of the fathers of the medical department of this University, and that the many generations of surgeons he has sent out into the world will cherish his memory with the kindest feelings. I am sure that I but reiterate the heartfelt wish of you all when I say that we trust to see him spared for many a day to give us his valuable counsel, and to watch the growth of the seedling which he has been instrumental in planting. We are also much indebted to others who have taken a warm interest in the founding of the Pathological Chair, and who from time to time have ventilated the question both in public and in private. You all know how strong the feeling of Professor Struthers has been in regard to it, and how, on every available occasion, he has impressed upon the profession and the public in general the urgent necessity which exists for the teaching of this subject. I trust that the wide experience he has had in matters of medical education, and the thoroughly sound views that he entertains in regard to it, will bear fruit in guiding us in making the teaching of pathology effective.

And now that the Chair has been founded, what are the objects we have in view; what is it that the subject of pathology is intended to teach ? In former times, pathology was termed the theory of medicine. The foundations of its teaching were the various theoretical notions of the structure and mechanism of the animal body, held by different sects of speculative philosophers. Thus the humorists, solidists, methodists, and dogmatists represented different schools, each founding upon a hypothesis whose truth could not be experimentally demonstrated. It was not until the beginning of the 17 th century that the curious notions of these speculative philosophers received their death-blow. Then it was that anatomy and physiology began to be systematically studied, scattering to the wind the theoretical notions of disease which had existed for the previous 2,000 years. The immortal Harvey had announced the facts of the circulation through the heart and larger bloodvessels (1628), and this was followed by the discovery of the capillary circulation by Malpighi (166r), and the fuller description of its phenomena a few years later by Leeuwenhoek (1674). The history of generation was also becoming a matter of inquiry. Men's eyes were, further, being opened to the great discoveries in other domains of natural science. Newton had imbued the philosophical world with a love of exact research. In Italy, a school of physicians, known as the iatro.mathematici, arose with Borelli (1669) as its chief supporter, who endeavoured to explain the functions of the body and action of remedies on the principles of mathematical and mechanical philosophy. The origin of animal heat was now referred to the friction of the circulating blood, the difference in secretions was explained by the proportional differences between the diameter, length, and curvature of 
the secreting vessels, and by the size of the angles at which an artery left the main trunk. Digestion was attributed to the grinding action of the stomach ; convulsions and pains to the tensions and vibrations of nerves. Although we now know that these ideas were in great part untrue, yet they formed a step in the right direction. The iatromathematicians, although they lacked the necessary preliminary knowledge to initiate such investigations, yet did much good by endeavourin introduce exactitude into their work, and to build statements upon a basis of fact. Something like a definite foundation for a true system of pathology was at length obtained, when, the beginning of this century, Bichat and Béclard divided the animal body into tissues, and when Schwann showed the cellular structure of these. It is from this epath that all our modern pathology dates; and since then a host of inpestigators has arisen, whose labours have accumulated, and are accumulating, with such rapidity that the assimilation of all that is written on the subject has become by no means an easy task.

It will be clear to you, therefore, that the old definition of pathology as the "theory of medicine" is no longer compatible with the nature of Its 'investigations, nor is it in keeping with the spirit of those who are engaged in pathological research. The old definition of pathology as the "theory of medicine" has therefore been discarded, and that of the "science of disease" has been substituted.

Pathology, or the Science of Disease, is, therefore, a young science. It has been begotten of previous investigations in normal anatomy and physiology. We are but on the threshold as yet, many of the facts already revealed being mere preliminaries in the elucidation of the problems which lie ungrasped before us. And in explanation of what I mean, I may here mention that the great aim which pathology as a science has in view at the present day, is the working out of the causes of disease. It isin thisdirection that the hills of difficultylie; it is here that the great opportunities for original research exist. In illustration of the darkness which prevails in regard to the cause of disease, let us take a single example-namely, that of the diseases of the skin. What do we know of their essential pathology? We recognise the appearance of a psoriasis or an eczema, and we give each a particular significant designation, but as to what their essential cause is, and why the skin should be so commonly an index of what we term a constitu. tional malady, we do not possess as yet the faintest conception. We have seen what, within a few years, has been revealed by the investigation of the etiology of zymotic diseases, but there are countless other problems equally as important, on the pathology of which we have no definite information. Depend upon it, the key to advancement in the treatment of disease is the study of its cause. We may grope about in the dark, treating disease empirically, and occasionally making a happy hit; but, as such, we are like an astronomer studying his subject without a knowledge of mathematics, or a mariner sailing without a compass.

The subject of pathology has resolved itself, at the present day, into three departments, which each require special attention. The first is that of morbid anatomy; the second, the knowledge derived from experimental inquiry; and the third, the valuable information we acquire through the comparative study of the diseases of the lower animals. As regards the first of these, I may say at once that it is the foundation of all therapeutical deduction. Unless we possess an accurate knowledge of the condition of diseased organs and tissues, and unless we have a clear mental picture constantly before us of what is occurring in the cells, vessels, and fibres of a part or organ in any disease, how is it that we can be expected to treat it rationally? Such of you as have not studied the subject, will be surprised to find what a new light is thrown upon disease, as you meet with it at the bedside, when you have gained a sound and thorough acquaintance with the changes parts undergo when subjected to this or that injurious agency.

No mere book-work will afford you this. You may have read al the text-books on morbid anatomy and histology, and yet you are far from being pathologists. Before you can conclude that you really possess a knowledge of any branch of natural science, you must observe for yourself, commit all sorts of blunders, have these pointed out to your read about it, forget it in great part, and, coming back to it again, at last get into the quiet haven of properly balanced opinion. $A$ wise man has said that there are three stages in acquiring true knowledge of a natural science-first, that in which you suppose you know everything about it; second, that in which you, in despair, seem to know nothing of it; third, the stage in which the pros and cons of the subject are properly adjusted in your mind. When you have gone through these three stages in the study of morbid anatomy, you will then be possessed of something which is no trouble for you to remem. ber, and which you can conjure up when occasion requires it of you.

In bringing about this happy result, it is essential that you gain a practical idea of the things that you are expected to learn. . It is of no use my merely talking to you for an hour daily, and imagining that thereby you are gaining instruction in morbid anatomy. This is a delusion long since exploded on the Continent, and, at last, beginning to force itself upon teachers in the medical schools of this country. For what is the advantage of teaching a scientific subject like this by merely repeating to you what can as well be set down in a text-book, and which you can peruse at your leisure? The only difference which I know is, that the latter is a much more agreeable method of gaining such instruction, being unaccompanied by the necessity of listening to what may prove to be anything but polished oratory. It is my earnest wish that the knowledge you acquire should not merely be book-work, but that, in every respect, the instruction you receive should be made as practical as possible. In gaining this practical knowledge, it is necessary that you learn it in a systematic manner. You must be taught, in fact, to observe. You may, perhaps, think it strange that I tell you this is necessary. Have we not all the faculty of yision you may say? Are we not all gifted with the power of looking at things? My reply is this; looking at things and observing them are two totally different processes. We are constantly looking at objects around us, but very few of us have the power of observing them. I never yet met with a beginner in the study of morbid anatomy who courd describe, in even comprehensible language, the simplest object set before him. The difficulty of the task you will find out only when you try it. Even among those who consider themselves authorities on this subject, the incongruity of their descriptions is, occasionally, lamentable. Want of accuracy is what is apparent, and no amount of mere words will suffice when this is deficient. You should be able to describe what you see in the shortest language possible. You should aim at curtness in all your writings or verbal statements. Avoid too many words, but let those you do employ be to the point.

Now, in order to learn this, you will have to go through a regular training. You will have to be shown your errors, and you will have to avoid these. No exercise could be -better for teaching you to use your observing faculties than the study of morbid anatomy. The variety of the objects you meet with is so great, that it may practically be said no two specimens of the same morbid lesion are alike.

For several years past $I$ have endeavoured to impress upon my students the urgent necessity of the study of ordinary naked-eye morbid anatomy. With beginners, there is always the tendency to imagine that naked-eye pathology, and the making of post mortem examinations, are uninteresting and unimportant studies, and that it requires a microscope to see anything worth while noticing. Nothing could be more fallacious. I wotild impress upon you not to rush to the microscopic examination of diseased parts and organs without having first exhausted all the information to be derived by your unaided vision.

I am inclined to think that histological or microscopic is easier than naked-eye or macroscopic observation; at least, I always find that you learn it more readily. You must undoubtedly become efficient observers with the microscope in order to make any progress, but remember that this ought to come secondarily to what I have told you in regard to the naked-eye description. The microscopical or histological study of lesions has made such rapid advances of late, and has become of such eminent importance, that no young medical man can be said to be educated at the present day, unless he be competent to examine any organ or tissue microscopically, and to form a correct opinion as to what the nature of the disease is. You will soon become competent to do this, if you are put in the right way of accomplishing it. Otherwise, you may spend years in useless labour, as I know too well from personal experience, withont making much advance. It is a difficult matier, you will admit, to learn to play on a musical instrument without some one to instruct and guide you. The same may be said in acquiring a knowledge of morbid histology.

It is, therefore, apparent that, in order to carry out this practical kind of teaching, we must have accommodation and appliances for the purpose, and these we have so far already acquired. We are now possessed in this University rot only of laboratories for teaching practical chemistry, natural history, botany, anatomy, physiology, and medical jurisprudence, but we have also accommodation for teaching pathology in a similar manner, which will compare favourably with any in the country.

It has been a scandalous state of matters that this subject, which has been practically taught in every small university on the Continent for many years past, has, in this country, up till lately, been totally neglected. A student, ardent to acquire a practical knbwledge of pathology, had formerly to seek for this the best way he copld. There was none to guide him, no systematic training which he could receive. Why is it that we have had to betake ourselves to 'foreigners to learn that which is the very backbone of all good medicine and surgery? 
Why is it that in this wealthy and enlightened country there was, until lately, only one university possessing a Pathological Chair? The necessity of pathological teaching has been recognised by the State for many years past in all other parts of Europe. Great Britain has, in this respect, been a by-word among European schools. Young graduates, on visiting the teaching medical centres of Germany and France, are taunted with the reproach of being incompletely educated. "You have obtained your degree in medicine", they say; "you come to us io get your education." Although this is certainly not a correct statement of the case, yet there is an air of truth in it; for not only does it: hold good of the subject of pathology, but in special clinical instruction, such as that of the eye, ear, and throat, we are as yet sadly deticient. In these, as was formerly the case in pathology, the student or young graduate is allowed to pick up a little knowledge here and there, as best he can. There are few institutions in this country where they are systematically taught. There are no qualifying bodies, I believe, that require a special knowledge of them. The result is that, probably, the first patient the young physician encounters, when ?aunched out into practice, is a sufferer in one of these organs. What is he to do? He has, perhaps, never seen an ear properly examined, has had few opportunities of using the laryngoscope, and his knowiedge of the eye is decidedly limited. The result is that he must hide his ynorance as best he can urder the cloak of a ponderous lengthy prescripiton, which may please the patient, and, let us hope, does him no harm.

It was not so long ago since there was hardly a laboratory in this country in which efficient accommodation for original research, even in physiology, could be obtained. Where did students formerly go to carry out the investigations necessary for a good physiological graduation thesis? To Germany and to France. And why was this so? Simply because neither were there the necessary appliances, nor did there exist those who were competent to guide or direct them to their studies. The usual answer to the student seeking to follow the paths of original work, either in physiology or pathology, was: "We have no leisure for instructing you; our practices are growing so extensive, that they absorb the whole of our time and energies. Go to the Continent, where men are specially supported by the State for imparting the knowledge you desire. "You will find none in this country willing, or competent, to do so." The result was, that those who had the means and time at their disposal, journeyed abroad in search of the knowledge they thirsted for; while those who were poorer, or whose engagements withheld from them the necessary leisure, were "unsatisfied in getting", and had to remain so.

I am very far from discouraging you from making a tour through the different medical schools of Europe after you have graduated; but what I do say is, that we ought, in the thoroughness of our education, to be in no respect inferior to that of our continental neighbours. I trust that such days of darkness are now past, and that the coming decade will see our medical schools provided with all the means and appliances necessary for making the education of their alumni what it ought to be.

There is another matter, however, to which it may be well that I here draw your attention, namely, that all instruction in medical science ought to have a direct bearing upon the clinical features of disease. Medicine is what you are to profess. Medical practitioners you are intended to become. Most of you are not to be pure physicists, chemists, physiologists, or pathologists, but all these subjects have to be correlated with the great aim of your life. You have to treat disease. That is the main object you must keep in view, and the successful accomplishment of it is that by which you will be chiefly judged by your patients. Never forget that it is the welfare of the patient that you have at heart, and bring all your acquirements in collateral studies to bear upon this.

Pathology is essentially one of those branches of medical science which is eminently utilitarian in its tendencies. Every observation you make in pathological work, every revelation you bring to light in its pursuit, has an immediate relationship to the treatment of disease. Any rational being will tell you that it is only natural to ascertain what is wrong before attempting a remedy; but, unfortunately, the reverse has only too often been the case in therapeutics. I have little hesitation in saying that it is by perfecting our knowledge in pathology that we may look to rendering treatment successful; and it is thus that our present empiricism may be swept away.

I have so far told you in general terms what are your duties as students of the subject. Let me now similarly advert for a little to a more personal matter-the qualifications of the teacher. In times gone by, before medicine could be said to have become a science at all, one man considered himself competent to teach several departments of the subject, and he was expected to be an authority on each. To a certain extent this was possible; for, in those days, medical education may briefly be said to have been comprised in the practice of medicine and surgery, and the teaching imparted was very much the sort of thing that an average general practitioner at the present day could impart to an apprentice. In this University, for example, there existed until the year 1839 a chair, the occupant of which was expected to teach the whole art and science of medicine. The Aberdeen Mediciner was the most ancient foundation (1522) for instruction in medicine in Great Britain.

In course of time, as medical science and practice began to develop, the impossibility of one man professing the whole subject became apparent. Separate professorships of anatomy, combined with surgery, and ultimately of anatomy pure and simple, became established. Others followed soon afterwards, until at the present day we find ourselves in Aberdeen with eleven Chairs of Medicine, the occupants of which devote themselves to teaching a particular branch. The reason for pathological anatomy being so long unrecognised as a subject worthy of special teaching was, that the preliminary subjects of normal anatomy, histology, physiology, and embryology had not become sufficiently well known. In fact, at the end of last century and beginning of this, the only subject in medical education which had any pretension to being a science was anatomy. It was not until Bichat, Johannes Muiller, Henle, Schleiden, and Schwann had demonstrated the structure of the various tissues, that a pathologist such as Virchow became a possibility. Hence it is, I dare say, that in this country there are so few centres of teaching the subject as a specialty. A specialty, and a very large and intricate one, it certainly has become; and, as such, I hold it ought to be taught by one who is willing to give his whole time and energies to it.

Do not let me send you away with the idea that, in making a pathological teacher, I would recommend a young graduate to commence the study of pathology, as a specialty, immediately after his student's career is over. If he does so, he will always be a narrow-minded observer, and will be apt to run in a particular groove. He will be unable to take a broad view of his subject, and will also fail in the allimportant point of connecting his teaching with the practice of medicine and surgery. Let him spend several years in the study of the clinical aspects of disease, before he begins to devote himself particularly to its causation.

And, further, do not let me be understood as implying that he should devote himself exclusively to the practice of physic. It is a common error to suppose that a pathologist must be a physician pure and simple. That, I hold, is an entirely false position for him to be placed in. Are the problems of surgery less worthy of being studied from a pathological point of view, than those of pure medicine? Is there in nature any hard and fast line between them? The pure physician now-a-days is apt to look down upon matters surgical. They are to many physicians quite foreign to their calling, and they would feel like the patriarchs of old, "unclean until the evening", did they, in the course of practice, meddle with anything out of their particular demesne. This is the man who is supposed to be cut out for a pathologist ! Could anything be more narrow-minded? Is it not in the observation of surgical disease, so called; in the study of the wonderful manifestations of physiological pathology as seen in repair, inflammation, suppuration, new growth, necrosis, septic infection, and a host of other problems that the most instructive lessons are to be derived? I go even further, however, and ask why should pure medicine or surgery form the limit of clinical study in a man wishing to teach the Science of Disease? Is the pathology of obstetrics and of gynæecology to be overlooked? Is there, in fact, any domain in medicine, taken in its comprehensive meaning, with which an intending pathologist should not be familiar? It is not necessary for him to become a specialist in any of its various departments, but the first thing for a teacher of the subject to do is to acquire a practical acquaintanceship with physic, surgery, obstetrics, and every other branch of medical practice, before laying himself out for the special labours of his life. It is of no use beginning to discuss the causes of disease, without, in the first place, knowing what disease is; and I hold that, even when engaged in the special duties of his office, a pathologist should always have his eyes open to the clinical history and living phenomena.

Not that I regard, as some do, the study of morbid anatomy as a "dead science", as it is called. If there is the eye to see, the lessons to be derived from morbid anatomy are all living studies. You call the inanimate material before you dead. Then so are the studies of ancient Greek statuary. There are some who can never see further than the marble. Its texture, to them, is everything. They are china fanciers, not artists. The classical lesson expressed by the marble is unperceived. So is it in the lessons left unprinted on the human marble. It is the classical lesson we wish to understand; the material in which that lesson is expressed is a matter of secondary importance.' 
A great composer is reported to have said that there was music in the clinking of pots and pans. So is it with every study in morbid anatomy. The something to be learned from it is not to be found by the superficial observer. It is the perceiving mind and the educated eye which alone will profit by it, and be able to reason from it.

Having acquired sufficient knowledge, not to make him a specialist either in medicine, surgery, or obstetrics, but such as will enable him to understand the usual manifestations of disease, I hold that if a man is going to be an efficient teacher of pathology, he should on no account be engaged in practice; and the real work of his life ought now to commence. Medical practice and the teaching of pathology are incompatibles, for not only must a teacher, in order to be efficient, be capable of explaining other men's views, but he must investigate everything for himself. Did the teaching of modern pathology consist in haranguing an audience for an hour daily for five months in the year, there is no reason why it should not be taken as a pleasant amusement in the course of the day's labours. This, however, I think, is hardly the sort of thing that it ought to be. The mere acting as a middle-man between those who are engaged in arduous investigation, and the listeners who are supposed to imbibe such teachings is, to say the least of it, not a very dignified position. It was not with this spirit that Carl Rokitansky, Rudolf Virchow, and John Goodsir made their fame. Their teachings were seasoned all through with the results of their personal labours ; not a résumé of the theories of this, that, and the other man. It is, no doubt, a convenient thing for a man to receive a large competency for delivering a paltry hour's lecture for five months in the year, and to occupy the rest of his time by attending to the duties of a lucrative practice. I cannot but think, however, that such is extremely bad for the institution with which he is connected. It is bad in several respects. It is bad as evincing a commercial instead of a truly scientific spirit. It is bad as an example to those who are supposed to profit by his teaching. It is bad as degrading the science he professes : and it is bad as showing that he is not in earnest with the work he has undertaken. Teachers of practice of physic, surgery, therapeutics, obstetrics, and such like branches require to be constantly engaged in bedside study, and the fact of their practising means that they are getting so much more experience of that which they undertake to teach. The pathologist's labours should, however, be directed in quite a different line. It is the etiology, or cause of disease, that he is expected to reveal, and it is not his domain to be engaged for the greater part of the day in its diagnosis and treatment. So long as we are in the bondage of darkness which at present exists in regard to our knowledge of the causes of disease, pathologists ought to spend the whole of their energies in throwing light upon them. In this way we aid in the advance of therapeutics; and, by showing how diseased conditions are brought about, confer a direct benefit both upon suffering humanity and the brute creation.

This is not to be accomplished by mere bedside observation. Far be it from me to lead you to suppose that you as pathologists should neglect the clinical features of any disease. I have said enough previously to warn you against this, but what I most emphatically state is, that little progress in the special study of modern pathology will be made, if attention be chiefly directed towards this. Mere symptoms and diagnosis have been observed and noted from the days of Hippocrates downwards, while the causation of disease is a study of a few years old. All the easy means of tracing disease to its origin have been exhausted. Methods much more intricate than those hitherto employed must be called in to our assistance. We must aim at the precision of the exact sciences. We must reduce our statements to the accuracy of chemical formulæ.

All this requires time, and I think that those of you who know what original research means, will agree with me that it is simply an impossibility for a man to teach the subject properly and to be engaged in complicated original research, while at the same time he lavishes his services upon the public as a practitioner of medicine. The Latin proverb- "Duos qui sequitur lepores, neutrum capit," holds good of pathology as of other undertakings in this life. "No man can serve two masters." We have had enough of the rough-andready self-confident investigator who: professes to be able to make all his analyses at the bedside, and who cannot see why everyore else should not do so likewise. Such pseudo-science is a species of quack. ery, and is worse than useless; it is misleading. In order to carry on reliable investigations in the great problems of pathology, we must bave laboratories for the purpose, we must possess instruments of precision, and must utilise the results of other sciences, studying their means of investigation, and adapting them to the end we have in view.

I have spoken thus strongly on a subject which I have thoroughly a heart. I feel that there is too much of the commercial element con- nected with scientific medical appointments in this country. Such a state of things is radically bad, and I have not the slightest hesitation in publicly denouncing it.

In this University, however, there is no chance of the Professor of Pathology being misled in the way I have indicated, seeing that he is bound down by the deed of foundation not to engage in practice. It seems to me that this is a wise regulation, and I trust that the benefit of it will be manifested in the illustrious line of professors of pathology who shall succeed me.

When I think what an intricate subject I have to teach, and when I consider how much responsibility rests upon me in teaching it, I fear for the result. Where the traditions and the practical working of a class are already established, it is a comparatively easy thing to slip into the beaten track. In the present instance, however, we shall be for some time, so to speak, exploring; and I only trust that we may be guided in all we do by a sense of justness and thoroughness. Above all things, let us discourage a supercilious dilettantism, and reach forward with a determined purpose, "Heart within, and God o'erhead." Remember the advice given by a personage not usually considered to be a sound adviser, but, nevertheless, good advice, to the ardent young student-

$$
\text { (iebraucht der Zeit, sie geht so schnell von hinne.., }
$$

The greatest of poets has declared that "All the world's a stage, and all the men and women merely players." In drawing aside the curtain from this, which, to you and to me, is one stage in our history, knowing, as I do, that you will play your part satisfactorily, I only trust that you will forgive the many shortcomings in the performance of mine. In the crude remarks which I have placed before you, there are many points which perhaps you may not see the force of at present; but, if in any respect these remarks have inspired you with zeal for a subject which is fraught with the deepest interest, I shall consider that my purpose in addressing you has been accomplished.

\section{A CONSIDERATION OF SOME OF THE CAUSES WHICH GIVE RISE TO DENTAL DECAY.* BY ALFRED CARPENTER, M.D., Croydon.}

Gentlemen, - When I consented, at the request of your President, io address you this session, I somewhat underrated the importance of the work I undertook to perform. I ought to have hesitated before agreeing to do a duty, which involved something more than the expression of my own views upon points concerning which I might have felt myself competent to advise you. But, having accepted the duty, it would scarcely be in accord with my ideas of an Englishman's character, if I did not at any rate attempt to do the work I had undertaken to perform. I propose, therefore, to follow up the line of thought which is ever in my mind upon the causation of disease, and to consider that subject in its relation to the teeth, on the principle that prevention is better and easier, in a large proportion of cases, than cure; and alsc, that there is a field for observations and practice here, as well as everywhere else in the domain of medicine and surgery.

This will especially apply to caries, and several other maladies which naturally come to the notice of the surgeon-dentist in the practice of his profession.

Are diseases of the teeth more common in our time than they were in the early days of civilisation? Has the artificial life in which we live now seriously damaged the dental organs, and has it promoted their earlier decay than was the case in the time of our forefathers?

To solve this question, we must go to ancient history. Diseases of the teeth were not unknown to those nations regarding whom we bave early records. We gather from Herodotus that there were dentists in Egypt in the times of the Pharaohs, and it is said that Belzoni discovered artificial teeth in the sarcophagi of the Egyptians. Erasistratus, Hippocrates, Heraclides of Tarentum, and other Grecian writers, speal: of diseases of the teeth as if they were not uncommon in their days: whilst Celsus describes the dentist's duty very accurately, and gives us a clear insight into the system in operation among the Romans in his time; Galen also is particular in his descriptions of dental diseases. Dental caries was common enough among the ancients; and, from all that we can learn, these diseases are not a new class, and do not therefore show a new departure in pathology. Yet there is sufficient evidence to tell us that luxury, indolence, and vice; tend very much to promole the development of such diseases, and to lay the foundation for those conditions which produce decay of all kinds in the dental organs, as well as elsewhere. This evidence is given by the state in 